\title{
The Error of using Degrees of Comparison in Adjectives
}

\author{
Bonari HR Tambunan, Juandi Nababan
}

Faculty of Teacher's Training and Education of Sisingamangaraja XII university of Tapanuli, East Java, Indonesia

\begin{abstract}
This study aim about the errors made by the students in using degrees of comparison in adjectives. The purpose of this study was to know the dominant type of the error. Error is associated with failure in competence. To find the data of the errors in using degrees of comparison in adjectives, this study was conducted by applying descriptive quantitative. The population was the ninth grade students of SMP Negeri 3 Muara Hutaginjang in academic year 2015/2016. The total population is 88 students, so the researcher took population as sample based on Arikunto' states. But in this study, the researcher took sample 84 students because 4 of them absent. The researcher used test for collecting the data. After collecting data, the researcher analyzed and classified the errors. The results of the data were the total of all errors is 841. The highest rate of all error types is misformation with the total of errors is 364 or $43,28 \%$ and the lowest rate of the error type is omission with 139 errors or 16,52\%. Next, there are 186 or $22,11 \%$ error in misordering and 152 or $18,07 \%$ in addition.
\end{abstract}

Keywords-Degrees Comparison; Adjectives.

\section{INTRODUCTION}

In globalization era, English is very important of international communication, because English is one of the international of the world. The importance of English language in this era cannot be denied. Many aspects of our lives is cannot be separated from the influence of English because it has many roles in techonology, sociocultural, economy, art, science, education and so forth. So, mastering English is necessary and become a challenge for every people. The general purpose of English study is to develop communicative competence in English both oral and written. Communicative competence involves the mastery of English language skills, they are listening, reading, speaking and writing. In listening skill, the students are expected to be able to understand the meaning of oral communication. Besides, in reading skill they are expected to be able to understand many kinds of English texts. Moreover, speaking in skill, the students are expected to be able to express their thought comprehensively. Also, in writing skill, they are expected to write their ideas meaningfully. By having the four English skills, the students are hoped to be able to develop their personal abilities for job or for higher level education. Students' problem in learning English may be caused by their inability to use language element such as structure, grammar, vocabulary, pronunciation, and spelling. This may create misunderstanding in communication. Based in Kurikulum Tingkat Satuan Pendidikan (KTSP) or Curriculum School Based, it is said that one of the based competence of teaching English for ninth grade students of Junior High School in Indonesia is expressing the meaning of simple short transactional (to get things done) and interpersonal dialogue accurately, fluently and grammatically. It means learners are expected to use English grammatically by following English structures which are known by native speakers.

\section{CONSTRUCTION OF COMPARISON}

Various expression of comparison are conveyed by different construction can be seen in the following explanation.

1. To indicate similarity (equality) the following pattern is usually employed :

As + positive + as

This pattern is usually in affirmative form.

Examples :

- I am as fast as you

- My house is as big as yours

In the negative form the following pattern is used :

Not as + possitive + as, or

Not so + possitive + as

Note that the "not as" is normally used in spoken (conversation) rather in written one.

Examples :

- Mt. Sibayak is not as high as Mt. Sinabung

- I am not so clever as you

Not also that whenthe last "as"is followed by a third person, ussually theverb is repeated.

Examples :

- Ani is not as tall as tina is.

- Badu is not as stupied as Edi is.

- Hadi is not so handsome as Teddy is.

2. To indicate the comparison of inequality the following pattern is usually employed.

Comparative + than 
Note that when a third person pronoun follows the "than"in followed by a first or second one, it is ussually possible to omit the verb.

Examples :

- He is wiser bthan you.

- You are taller than he is.

- She has more money than I.

3. To indicate the comparison of more than two person or things, the following pattern are ussually used :

The + superlative + of ... (of groups)

The + superlative + of ...( of place $)$

Examples :

- She is the prettiest of them all.

- Ali is the cleverest student in our class.

- Mary is the most diligent student in that club.

4. To indicate the paralel increase the following pattern is ussually used :

The + comparative....... The comparative.

Example :

- The more we pracrices, the bettert the result will be.

- The longer we live, the more problems we will face.

- The happier you are,the more wealther you will be.

\section{The Form of Adjective Comparison}

The adjective change their form to express different of quality one of them is comprative degree. There are some groups or exceptions of comparative form. In comparison of adjective there are two forms, they are regular comparison and irregular comparison forms. Richard (1970: 174) characterized three sources of errors; they are interference errors, intralingua errors and developmental errors.

1) Interference Errors occur as a result of "the use of elements from one language while speaking another". It is also said that students who learn English as a second language, and when first language and English came into contact with which each other there are often confusions' which provoke errors in a learner's use of English Brown called this term as interlingual transfer, he said that in the stage, before the system of the second language is familiar, the native language is the only linguistic system which the learner can draw.
For example, the learner said "the book of Jack" instead of "Jack's book".

2) Intralingual Errors are these which reflect the general characteristic of rule learning such as faulty generalization, incomplete application of rules, and failure to learn conditions under which rules apply.

3) Developmental error occur when the learner attempt to build up hypothesis about the target language on yhe basis of limited experience of it in the classroom or text book. Brown called this term as "context of learning" instead of developmental errors.

Errors occur for many reason, still in explaining learners' errors the researcher uses Brown terms : interlingual transfer, intralingual transfer, and context of learning. In interlingual errors, a student may make error because he/she assumes that the target language and his native language are smiliar, in fact they are different. Another obvious cause is an incomplete knowledgeof the target language and the complexity of target language.the error occurs because of the difficulty of processing forms that are not yet fully master, which is known as intralingual errors and context of learning is also the cause of errors. In this case, the book or the method being use in teaching learning process do not suit the students, so it may cause the students cannot understand the material being learn and the students less motivated.

\section{METHODOLOGY}

This research had conducted by applying descriptive quantitative design. Quantitative research design was characterized by the assumption that human behavior can be explained by what may be term social fact, which can be investigated by the methodologies that utilize the deductive logic at the natural science (Home, 1994:121). It means that the study used numbers to analyze the data. The researcher analyzed the errors of the use degrees of comparison in adjectives by the ninth grade students of SMP Negeri 3 Muara Hutaginjang. The researcher described the students' errors in testing degrees of comparison in adjectives by using percentages of students' errors. The researcher came to school in order to get data. The data required is the information of the students' answer sheets on the use of degrees of comparison in adjectives which were given by the researcher. Furthermore the data are analyzed statistically.

\section{RESULT AND DISCUSSION}

Table: The percentages of students' error in each type

\begin{tabular}{|c|c|c|c|}
\hline No. & Types of Error & Frequency of Error & Percentage of Error \\
\hline 1 & Misformation & 364 & $\frac{364}{841} \times 100 \%=43,28 \%$ \\
\hline 2 & Misordering & 186 & $\frac{186}{841} \times 100 \%=22,11 \%$ \\
\hline
\end{tabular}




\begin{tabular}{|c|c|c|c|}
\hline No. & Types of Error & Frequency of Error & Percentage of Error \\
\hline 3 & Addition & 152 & $\frac{152}{841} \times 100 \%=18.07 \%$ \\
\hline 4 & Ommission & 139 & $\frac{139}{841} \times 100 \%=16.52 \%$ \\
\hline & Total & 841 & $100 \%$ \\
\hline
\end{tabular}

\section{CONCLUSIONS}

After analyzing the data from the student' errors on the using degrees of comparison in adjectives, the conclusions can draw as the types of error committed by the ninth grade students of SMP Negeri 3 Muara Hutaginjang are error of misformation $43,28 \%$, error of misordering $22,11 \%$, error of addition $18,07 \%$ and error of omission $16,52 \%$. So the dominant error is error of misformation that $43,28 \%$.

\section{REFERENCES}

[1] Arikunto, Suharsimi. 1997. Prosedur Penelitian: Suatu Pendekatan Praktek. Jakarta: Rineka Putra.

[2] Azhar, Betty Schrampfer. 2002. Understanding and Using English Grammar. New York

[3] Longman.Brown, H. Douglas. 2006. Principles of Language Learning and Teaching. New York: Pearson Education.

[4] Corder, S.P. 1981. Error Analysis and Interlanguage. New York: Oxford University Press.

[5] Curme, George O. 1947. English Grammar. New York : Barnes \& Noble.

[6] Dulay, Heidi, Burt, Marina, and Krashen, Stephen. 1982. Language Two. New York: Oxford University Press.

[7] Ellis, Rod. 2008. The Study of Second Language Acquisition, Oxford: Oxford University Press.

[8] Frank, Marcella. 1972. Modern English : A practical Reference Guid. Englewood Cliffs - Prentice hall. 